logos_i_ethos_2021_2_(58), s. 185-190

https://doi.org/10.15633/lie.4176

\title{
Aleksander Bobko
}

https://orcid.org/0000-0003-0609-6982

Uniwersytet Papieski Jana Pawła II w Krakowie

\section{O potrzebie głębszego wymiaru polityki}

\section{Recenzja książki Jerzego W. Gałkowskiego, Dobro wspólne a polityka, Wydawnictwo KUL 2020}

Mogłoby się wydawać, że na temat myśli i działalności Jana Pawła II powiedziano już wszystko. Prezentowana książka - napisana przez prof. Jerzego Gałkowskiego, który był bezpośrednim uczniem prof. Karola Wojtyły (w 1967 roku obronił doktorat przygotowany pod jego kierunkiem) - choć nie zawiera jakichś rewelacyjnych nowinek, daje bardzo rzetelny i uporządkowany wykład swoistej doktryny politycznej polskiego papieża. Jej fundamenty mają charakter teologiczny i filozoficzny, a treścią jest społeczne nauczanie Kościoła. Centralnym elementem tej doktryny jest idea dobra wspólnego. Zamiarem autora jest rekonstrukcja i usystematyzowanie myśli dotyczącej kwestii społecznych, a sprawą kluczową jest pokazanie związku pomiędzy teoretycznym (filozoficzno-teologicznym) dorobkiem Karola Wojtyły a późniejszym nauczaniem społecznym Jana Pawła II. Prezentowane analizy są niekiedy uzupełniane przez profesora Gałkowskiego (w sposób bardzo oszczędny i dyskretny) własnymi przemyśleniami i postulatami. W tych fragmentach można odnaleźć inspirację bieżącymi wydarzeniami oraz troskę o jakość życia publicznego w Polsce i Europie.

Książka składa się z czterech rozdziałów i zakończenia. W rozdziale pierwszym znajdujemy próbę doprecyzowania tego, jak współcześnie ujmowana jest sfera polityki. W tej kwestii pojawia się ogromna liczba 
różnorakich koncepcji, autor wskazuje na kilka ważnych aspektów tego zagadnienia. Najpierw analizuje związek pomiędzy państwem a polityką, rzeczą ważną jest tutaj sprawa źródła praw i relacja pomiędzy legalnością a słusznością działania, a także legalizacja i zakres działania władzy. Choć życie polityczne toczy się głównie w ramach państwa - kształtowane jest przez prawo i instytucje (s. 30) - to jednak „redukowanie polityki jedynie do problemu państwa... jest daleko niewystarczające” (s. 34). W tym miejscu pojawia się kluczowy dla całej książki motyw: próba powiązania polityki ze sferą wartości. Autor zarysowuje dwie najbardziej popularne tradycje w europejskiej myśli politycznej (s. 38-46): liberalną (odwołując się przede wszystkim do Immanuela Kanta) oraz autorytarną (nawiązując do Carla Schmitta). Jednak w obu tych tradycjach zbyt małą rolę odgrywa idea dobra wspólnego. Jan Paweł II w sposób szczególny nawiązywał do tej właśnie idei, która otwiera możliwość tworzenia wspólnoty, gdzie „członkowie relacji, działając wspólnie, osiągają też wspólną korzyść, i to wyższą, niż gdy działają osobno” (s. 47).

Aby możliwe było rozpatrywanie polityki w perspektywie wartości (a w szczególności dobra wspólnego), konieczne jest wskazanie jakiegoś stałego punktu odniesienia. W przekonaniu Karola Wojtyły - Jana Pawła II takim fundamentem jest doświadczenie człowieka (s. 49); człowiek jest zarówno „drogą Kościoła”, jak i wyznacznikiem refleksji i praktyki politycznej. Stąd rozdział drugi poświęcony jest analizie antropologicznego podłoża działania społecznego. Na początku prof. Gałkowski pokazuje różnice pomiędzy charakterystyczną dla Wojtyły zasadą personalistyczną a dominującym we współczesnej kulturze utylitaryzmem: pojęcie osoby harmonizuje aspekt osobisty i aspekt społeczny, człowiek jako osoba uczestniczy w życiu społecznym (s. 59). Dla właściwego odczytania tego fundamentalnego doświadczenia, jakim jest człowiek, istotne są dwa momenty: odkrycie prawdziwej natury ludzkiej, ale także rozpoznanie zmieniających się postaw, które mają charakter „znaków czasu”. Według Jana Pawła II współcześnie takim „znakiem czasu” jest "rosnąca potrzeba uczestnictwa. Stanowi ona niewątpliwie jedną z charakterystycznych cech współczesnej ludzkości” (s. 61). Znakiem czasu jest również „wyostrzona wrażliwość na prawa człowieka i na wartość 
demokracji" (s. 102, 117). Natomiast tworzenie wspólnoty politycznej nie jest tylko działaniem czysto pragmatycznym - realizacją jakiejś umowy społecznej czy odpowiedzią na zagrożenia - jest to „proces wynikający z samego sposobu istnienia człowieka, z jego wnętrza, z jego przeżyć, które są złożone i wyrażają całość jego istnienia" (s. 72). Ta myśl, która próbuje pokazać głębsze podłoże polityki, w ujęciu prof. Gałkowskiego stanowi centralny element doktryny papieża i jest głównym przesłaniem całej książki.

Przesłanie to konkretyzuje się w idei dobra wspólnego. Na początku rozdziału trzeciego znajdujemy zarys historii tego pojęcia, które nie jest jednoznaczne. Współcześnie idea dobra wspólnego i rozumienie polityki jako „roztropnej troski o dobro wspólne” są kojarzone ze społeczną nauką Kościoła. W tej materii autor wskazuje na wielki dorobek Jana Pawła II. Realizacja dobra wspólnego jest czymś więcej niż podejmowaniem wspólnych przedsięwzięć dla realizacji jakiegoś celu. W wizji personalistycznej wskazuje się na „możliwość dokonania przemian w samym podmiocie działającym, na rozwój osoby, na kształtowanie w nim postaw autentycznych" (s. 88). Tak rozumiana polityka to nie tylko sprawne i pragmatyczne działanie w sferze przedmiotowej, lecz także kształtowanie człowieka i wspólnoty. Warunkiem takiego ujęcia polityki jest właściwe rozumienie godności człowieka, która jest czymś naturalnym i stanowi ostateczny „punkt odniesienia moralności, kryterium dobra i zła" (s. 97). Pełne zaakceptowanie godności odsyła do korzeni wiary i religii - w godności, której treścią jest wolność i rozumność człowieka, konkretyzuje się podobieństwo człowieka do Boga. W sferze polityki natomiast kluczowa jest wartość prawdy, która musi wychodzić poza obszar subiektywnych przeżyć. Bez oparcia się na prawdzie, prędzej czy później, siła weźmie górę nad racjami, a system polityczny będzie dryfował w stronę totalitaryzmu. Stąd Jan Paweł II wskazuje na dwa filary porząaku politycznego: filarem przedmiotowym jest prawo, a podmiotowym cnoty obywatelskie polegające na „uznaniu wyższości dobra wspólnego nad indywidualnym interesem" (s. 106).

Rozdział czwarty wypełnia analiza idei dobra wspólnego w różnych bardziej konkretnych wymiarach. Pojawiają się tutaj między innymi 
takie idee i zagadnienia, jak solidarność, prawa człowieka, praca, demokracja, globalizacja, ekologia. We wszystkich tych punktach autor sięga do tekstów papieskich (zwłaszcza encyklik oraz licznych wystąpień oficjalnych), próbując pokazać, jak Jan Paweł II transponował abstrakcyjną ideę dobra wspólnego na bardziej konkretne przesłania kierowane do wielu wspólnot, a ostatecznie do wszystkich ludzi dobrej woli. Jednym z przewijających się tutaj wątków jest na przykład usilne przekonywanie do tego, że prawo powinno stać ponad siłą (s. 119, 137). Idea ta jest szczególną zdobyczą cywilizacji zachodnioeuropejskiej i należy o niej nieustanie przypominać i chronić ją wszelkimi sposobami. Innym ciekawym i powtarzającym się motywem jest naturalne w przestrzeni politycznej napięcie pomiędzy egoizmem a altruizmem (s. 153, 183, 194). Jest rzeczą naturalną, że człowiek dba przede wszystkim o własne interesy, i ta tendencja może się silnie ujawniać zwłaszcza w życiu politycznym. Jednak „ze względu na realizm życia wydaje się potrzebne, a nawet konieczne zrównoważenie widzenia roli interesu jednostki - obywatela, mojego ja, oraz drugiego i drugich" (s. 183). Takie otwarcie na dobro wspólne umożliwia tworzenie autentycznej wspólnoty: zarówno w wymiarze państwowym (prowadząc do ugruntowania społeczeństwa obywatelskiego), jak i w wymiarze międzynarodowym, dając fundamenty dla pokoju. Trwały pokój nie jest bowiem możliwy jedynie w oparciu o siłę, „ale jest także owocem miłości, która posuwa się poza granice tego, co może wyświadczać sama sprawiedliwość". Domknięciem prowadzonych tu rozważań jest wskazanie na rolę kultury, która „skierowana jest w sposób bezinteresowny i naturalny na dobro wspólnoty i całego społeczeństwa” (s. 213). Jak mówił Jan Paweł II, „kultura jest tym, przez co człowiek staje się bardziej człowiekiem” (s. 214). W konkluzji pojawia się stwierdzenie, że pojęcie polityki i kultury są $\mathrm{w}$ istocie sobie bliskie: „kultura jest bliższa wartościom..., natomiast polityka jest raczej narzędziem troski o te wartości” (s. 223).

Książkę prof. Jerzego Gałkowskiego można odczytywać w dwóch perspektywach. Po pierwsze jest to usystematyzowane kompendium myśli politycznej Karola Wojtyły - Jana Pawła II: opatrzone bogatą bibliografią oraz cytatami z najważniejszych prac i wystąpień, stanowi znakomity 
przewodnik po świecie głębokiej myśli teologiczno-filozoficznej oraz praktycznych rekomendacji kierowanych przez polskiego papieża do współczesnego świata. Jest to opracowanie tym bardziej autentyczne i cenne, że zostało napisane przez jego bezpośredniego ucznia. Profesor nie epatuje swoją bliską relacją z papieżem, ale w prezentowanym tekście daje się „wyczuć”, że jest to refleksja swoistego „świadka”, który przez kilka dekad towarzyszył swojemu Mistrzowi na ścieżkach intelektualnych poszukiwań prawdy i wypełniania niezwykłej społecznej misji. W tym sensie jest to jedyna w swoim rodzaju pozycja w zbiorze bardzo licznych opracowań na temat dorobku Jana Pawła II.

Po drugie, wydaje się, że autor pragnie skierować do człowieka żyjącego we współczesnej kulturze "nieśmiałe przesłanie” wskazujące na to, czym mogłaby być (i czym w istocie powinna być) polityka. W niespełna dwie dekady po śmierci papieża świat i Europa zmieniły się w bardzo zasadniczy sposób: w kulturze coraz bardziej zdaje się dominować konsumpcjonizm, utylitaryzm i płytki pragmatyzm; w sferze polityki postępuje radykalizacja poglądów i postaw, a relacje polityczne sprowadzają się do bezwzględnej walki z rzeczywistym albo wyimaginowanym przeciwnikiem/wrogiem. Pozycja tradycji chrześcijańskiej i głos Kościoła katolickiego są systematycznie marginalizowane. Tymczasem autor cierpliwie powtarza, że w praktyce politycznej konieczne są zaufanie, wzajemny szacunek pomiędzy przeciwnikami/partnerami, odwoływanie się do racjonalnych argumentów (a nie siły) oraz poszukiwanie kompromisu. Aby to było możliwe, bieżące życie polityczne musi opierać się na głębszych fundamentach, czyli odwoływać się do wartości, do dobra wspólnego. Taką centralną wartością jest obdarzony wolnością i rozumem człowiek - istota o jedynej w swoim rodzaju godności. Owa godność nie realizuje się przez płytki indywidualizm - przekonanie, że moja subiektywna (najczęściej emocjonalnie podjęta) decyzja jest ostateczną miarą rzeczywistości. Godność nabiera właściwego sensu na tle obiektywnego świata wartości, których ostatecznym fundatorem jest Bóg, a nie człowiek. Wychodząc z takich przesłanek Karol Wojtyła - Jan Paweł II wyjaśniał zjawiska życia społecznego i odpowiednio do tego, konsekwentnie promował w swojej działalności jako profesor, 
biskup i papież wizję polityki opartej na idei dobra wspólnego. Niestety, to piękne przesłanie, opisane przez jego ucznia w książce Dobro wspólne a polityka, wydaje się być $\mathrm{w}$ realiach współczesnej kultury i polityki w sposób szczególny „nie na czasie”. 